ULFIYANA LATIFAH DAN AGUS MULYANA

PEMIKIRAN MAHBUB DJUNAIDI TENTANG AGAMA DAN POLITIK PADA TAHUN 197O-1995

\title{
PEMIKIRAN MAHBUB DJUNAIDI TENTANG AGAMA DAN POLITIK PADA TAHUN 1970-1995
}

\author{
Oleh: \\ Ulfiyana Latifah, Agus Mulyana ${ }^{1}$
}

\begin{abstract}
Mahbub Djunaidi is a thinker figure from Nahdlatul Ulama. When he became a columnist in 1970-1995, many of his thoughts poured in the newspapers. In the article, Mahbub Djunaidi talked about things related to religious and political aspects. This study outlined the question "How was Mahbub Djunaidi's thought about religion and politics in 1970-1995?" To answer the question, this study used historical methods which consist of the heuristic stage, source criticism, interpretation and historiography as well as the research technique of literature study and interviews with some relevant sources from the problems researched. Based on the results, it could be found that Mahbub Djunaidi was a columnist from the Nahdlatul Ulama circle which in his writing poured many thoughts on religion and politics. His thought towards religion in 1970-1995 discussed many things social life that can not be separated from Ahlussunnah Wal Jama'ah. Whilst his thought about politics discussed many things about the relationship between Islam and the state, as well as the relationship between Nahdlatul Ulama and the state that can not be separated from the democracy school of thought. This research is expected to be a reference for the next research, so it can present new facts that have not been revealed from this research.
\end{abstract}

Keywords: Ahlussunnah Wal Jama'ah, Democracy, Mahbub Djunaidi, Nahdlatul Ulama

\section{PENDAHULUAN}

Di dalam setiap pemerintahan di Indonesia terdapat beberapa pemikiranpemikiran politik yang sangat berpengaruh terhadap sistem pemerintahan yang ada serta berpengaruh terhadap kehidupan sosial. Pemikiran-pemikiran politik tersebut diantaranya ialah pemikiran politik komunis, sosialis, nasionalis, dan Islam. Salah satu pemikiran politik yang sangat kuat di Indonesia adalah pemikiran politik Islam. Hal ini di karenakan pemikiran politik Islam merupakan pemikiran yang berasal dari Indonesia.

Di dalam setiap periode pemerintahan pemikiran Islam selalu ada. Pada masa pemerintahan Orde Lama umat Islam memainkan peran yang sangat besar dalam menghadapi kekuatan komunis di Indonesia. Gagasan negara Islam harus berhadapan dengan gagasan negara nasional berdasarkan Pancasila. Di dalam masa pemerintahan Orde Baru Islam

${ }^{1}$ Ulfiyana Latifah adalah mahasiswa Departemen Pendidikan Sejarah FPIPS UPI, Agus Mulyana adalah Dosen Pembimbing. Penulis dapat dihubungi di alamat email : Ulfiyanalatifah@gmail.com 
mengalami pasang surut. Putra (2008, hlm. 187) mengemukakan bahwa :

"Posisi umat Islam dan pemerintah era Orde Baru periode pertama berada dalam posisi berhadapan (vis a vis), ditambah dengan berbagai kasus yang semakin merenggangkan hubungan tersebut, sebutlah kasus Tanjung Priok, Lampung, Peledakan Borobudur dan lain-lain. Ini terjadi karena orangorang dekat Soeharto kebanyakan dari kalangan non muslim, para Jendral militer didominasi oleh golongan anti Islam".

Ketika Orde Baru lahir, umat Islam mulai menaruh harapan besar untuk menyelenggarakan pemerintahan yang demokratis karena para politisi Islam mulai dilepaskan dari penjara. Mereka seakanakan sudah dapat kembali ke dalam dunia politik. Namun, pada pemilu 1971 puncak kegagalan politik Islam untuk kembali berkiprah karena hasil pemilu pertama Orde Baru pada tahun 1971 membawa kemenangan mutlak kepada Golkar sedangkan partai Islam memperoleh jatah suara yang kecil. "Kenyataan pahit pemilu 1971 semakin mengentalkan rasa putus asa, bahkan kemarahan umat Islam. Kepedihan itu mengingat kecurangan dan pemaksaan pemerintah dalam proses pemilu tersebut"(Effendi, 2013, hlm. 97).

Pada masa pemerintahan Orde Baru muncul seorang pemikir politik Islam dari kalangan Nahdlatul Ulama (NU) yakni Mahbub Djunaidi yang pemikiranpemikirannya selalu dituangkan ke dalam tulisannya ketika menjadi seorang kolumnis. Kegemaran dalam menulis mulai meningkat ketika duduk di bangku SMP dan ketika SMA tulisan-tulisannya sudah dimuat di majalah-majalah bergengsi, seperti Siasat (sajak), Mimbar Indonesia (esai), Kisah, Roman, Star Weekly, Tjinta (cerita pendek). Ia terjun ke dunia jurnalistik pada tahun 1958 mengisi Harian Duta Masyarakat yang kemudian ia menjadi Pemimpin Redaksinya pada tahun 1960-1970 (Puspitasari, 2013, hlm. 3).

Ketika menjadi seorang kolumnis dan aktif di dalam organisasi Islam, Mahbub Djunaidi mulai memasuki dunia politik terutama pada masa pemerintahan Orde baru. Mahbub Djunaidi pun banyak mengkritik tentang kehidupan sosial terutama pada aspek agama dan politik. Menurut Mahbub Djunaidi masyarakat IslamdiIndonesiasangatmemperihatinkan dalam dunia politik, meski di dalam menjalankan syariat keagamaan cukup membanggakan (Setiawan, 2016, hlm. 4). Pemikirannya tersebut banyak dituangkan ke dalam hasil-hasil karya tulisannya semasa menjadi seorang kolumnis di Kompas dan karya buku-buku lainnya. Mahbub Djunaidi memiliki gaya penulisan yang unik, humoris dan menggunakan metafora-metafora yang sering mengagetkan pembaca dan menajamkan sorotannya. Salah satu gaya metafora Mahbub Djunaidi sebagai berikut :

Priayi itu sebangsa manusia juga, tapi tidak semua manusia dapat disebut priayi. Zaman dulu, seorang ambtenar atau orang berdarah biru, tidak senang disebut "Orang" melainkan "Priayi". Ibarat jambu, priayi itu "Jambu Bangkok". Ibarat lele, Priayi itu "Lele Jumbo". Priayi itu merasa mempunyai martabat berlebih. Sebagian disebabkan oleh prestasi, sebagain tidak disebabkan apa-apa. Opini yang sudah terbentuk bertahun-tahun menobatkan priayi itu di atas anjungan, berbeda dengan 
orang kebanyakan (Djunaidi, 1996, hlm. 215).

Berdasarkan pemaparan di atas, peneliti tertarik untuk mengupas lebih jauh tentang riwayat hidup Mahbub Djunaidi sebagai tokoh NU sehingga bisa menjadi seorang kolumnis . Peneliti juga ingin mengetahui bagaimana pemikiran Mahbub Djunaidi tentang agama dan politik ketika menjadi seorang kolumnis yang dituangkan ke dalam tulisannya dari tahun 1970 hingga Mahbub Djunaidi wafat pada tahun 1995 .

\section{METODE PENELITIAN}

Metode yang digunakan dalam penulisan jurnal ini adalah metode historis atau metode sejarah. "Metode sejarah adalah proses menguji dan menganalisis secara kritis terhadap rekaman serta peninggalan masa lampau"(Gottschalk, 2008, hlm. 39). Metode sejarah pun merupakan metode penulisan yang bersifat sistematis dan terarah untuk menguji serta menganalisis sesuatu hal yang pernah terjadi sesuai dengan prosedur dan teknik yang sudah ditentukkan.

Pada umumnya ada enam tahap yang harus ditempuh dalam penelitian sejarah yakini :

1. Memilih suatu topik yang sesuai;

2. Mengusut semua evidensi (bukti) yang relevan dengan topik;

3. Membuat catatan tentang apa saja yang dianggap penting dan relevan dengan topik yang ditemukan ketika penelitian sedang berlangsung;

4. Mengevaluasi secara kritis semua evidensi yang telah dikumpulkan (kritik sumber);

5. Menyusun hasil-hasil penelitian (catatan fakta-fakta) ke dalam suatu pola yang benar dan berarti yaitu sistematika tertentu yang telah disiapkan sebelumnya;

6. Menyajikannya dalam suatu cara yang dapat menarik perhatian dan mengkomunikasikannya kepada para pembaca sehingga dapat di mengerti ( Wood Gray dalam Sjamsuddin, 2007, hlm. 89).

Dalam penelitian ini, peneliti menggunakanmetodesejarahsebagaimana yang dijelaskan oleh Ismaun (2005, hlm. 50) yang mengemukakan bahwa dalam metode sejarah meliputi.

1. Heuristik (pengumpulan sumbersumber).

2. Kritik atau analisis sumber (eksternal dan internal).

3. Interpretasi (penafsiran).

4. Historiografi (penulisan sejarah)

Dalam penelitian ini peneliti menggunakan pendekatan interdisipliner. Melalui pendekatan interdisipiliner ini, peneliti dapat meminjam sudut pandang disiplin ilmu yang lain untuk membantu ilmu sejarah dalam mengkaji permasalahan-permasalahan yang terdapat pada rumusan masalah penelitian. Peneliti pun melakukan rekonstruksi mengenai masa lampau dengan menggunakan studi literatur dan wawancara sebagai teknik penelitiannya.

\section{HASIL PENELITIAN DAN PEMBAHASAN}

Mahbub Djunaidi merupakan anak pertama yang lahir dari pasangan $\mathrm{H}$. Djunaidi dan ibu Muchsinati di Jakarta pada hari Kamis tanggal 22 Juli 1933. Ketika Mahbub Djunaidi lahir, Indonesia 
masih berada dalam masa penjajahan. Ia dan keluarganya harus beberapa kali pindah dari Jakarta ke Solo untuk menghindari pertempuran fisik antara Belanda dengan para pejuang Indonesia. Akibatnya ia menghabiskan masa kecilnya di Solo, Jawa Tengah.

Ayahnya merupakan seorang Kiai dari kalangan Nahdlatul Ulama (NU) yang pernah menjadi anggota DPR hasil pemilu tahun 1955 dan pernah menjabat sebagai kepalabiroperadilandi Kementrian Agama. Ibunya merupakan campuran antara Jerman dengan Indonesia. Nama kakek dari pihak ibunya adalah Muhammad Alwi alias Louis yang menikah dengan gadis asli Betawi (nenek Mahbub). Sedangkan nama kakek dari pihak ayah adalah Abdul Aziz bin Sainan dan neneknya bernama Siti Hasanah (Setiawan, 2016, hlm. 15).

Sejak kecil Mahbub Djunaidi sangat gemar menulis. Kegemaran dalam menulis semakin meningkat ketika cerpennya yang berjudul "Tanah Mati" dipublikasikan oleh majalah Kisah pada bulan Maret tahun 1950. Cerpen tersebut diberi penilaian serta komentar oleh HB Jassin yang dijuluki sebagai paus sastra Indonesia. Hingga pada akhirnya banyak karyanya yang dipublikasikan oleh majalah-majalah ternama di Indonesia. Budairy (dalam Djunaidi, 1996, hlm. xx) mengatakan bahwa "di luar urusan dengan majalah sekolah, tulisan-tulisan Mahbub Djunaidi telah dimuat di majalah-majalah bergengsi seperti Siasat (puisi), Mimbar Indonesia (esai), Kisah, Roman, Star Weekly, Cinta (cerpen)".

Art Buchwald, Anton Chekov, Pramoedya Ananta Toer dan Ir. Soekarno merupakan penulis yang sangat digemari oleh Mahbub Djunaidi. Menurutnya masing-masing penulis memiliki kelebihan dan ciri gaya penulisan yang berbedabeda. Misalnya, Ir. Soekarno memiliki gaya penulisan yang revolusioner sesuai dengan bahasa lisannya. Anton Chekov selalu memberikan pesan moral dalam tulisannya. Art Buchwald dalam gaya menulisnya selalu memakai gaya humor untuk menyindir kapitalisme Amerika sedangkan Praomedya memiliki energi yang super dalam mencari data primer dan sangat jelas dalam menuturkan sebuah peristiwa, egosentris dan humanis (Isfandiari, Wawancara, 9/3/2018).

Kegemaran dalam menulis terus dikembangkan hingga pada akhirnya Mahbub Djunaidi menjadi seorang kolumnis dengan memiliki ciri gaya penulisan yang khas dan unik. Sastra Rusia merupakan sastra yang sangat disenangi oleh Mahbub Djunaidi. Mahbub Djunaidi berpandangan bahwa sastrawan Rusia banyak melahirkan karya sastra yang sarat dengan kritik tajam dan dituturkan secara satire. Humor-humor kecil menjadikan kritik-kritik tersebut mengesankan. Sehingga sastra Rusia sangat memberikan pengaruh terhadap tulisan-tulisannya yang selalu menggunakan humor untuk melihat fenomena kehidupan.

Mahbub Djunaidi memulai pendidikan Formal di Sekolah Dasar (SD) pada tahun 1940 di daerah Solo. Ia dan keluarganya harus pindah mengungsi ke Solo karena kondisi Jakarta tidak aman ketika Indonesia masih berada di bawah penjajahan. Ketika menginjak usia 15 tahun Mahbub Djunaidi baru duduk di kelas 1 SMP (Sekolah Menengah Pertama) pada tahun 1949. Hal ini pun diperkuat oleh pernyataan dari Setiawan (2016, hlm. 22) yang mengatakan bahwa : 
"Pada tahun 1946 sampai dengan tahun 1949, tepatnya ketika masa revolusi fisik terjadi yaitu Agresi Militer Belanda I, keluarga Mahbub mengungsi ke Solo. Mahbub mulai pendidikannya di Solo dari Sekolah Dasar sampai lulus Sekolah Menengah Pertama (SMP)".

Pada tahun 1952 Mahbub Djunaidi dan keluarganya kembali lagi ke Jakarta dan meneruskan pendidikan Sekolah Menengah Atas di Budi Utomo. Ketika duduk di bangku SMA mulai aktif mengikuti organisasi dan kegemaran menulisnya pun semakin meningkat. Banyak tulisannya yang dimuat di berbagai media massa. Hal ini diperkuat oleh pernyataan Budairy (dalam Djunaidi, 1996, hlm. xx) yang mengatakan bahwa "di sekolah itu Mahbub Djunaidi mengambil prakarsa mengusulkan agar sekolah menerbitkan majalah. Kemudian terbitlah majalah Siswa. Terbitan perdananya bertanggal 6 Desember 1954. Pemimpin redaksi pertamanya Mahbub Djunaidi sendiri”.

Setelah lulus SMA, Mahbub Djunaidi melanjutkan pendidikan di Perguruan Tinggi di Fakultas Hukum Universitas Indonesia, akan tetapi tidak selesai hanya pada sampai tingkat II. Hal tersebut dikarenakan ayahnya sakit dan ketiadaan biaya. Mahbub Djunaidi rela drop out karena memiliki rasa sayang dan tanggung jawab terhadap adik-adiknya sebagai anak pertama yang menjadi tulang punggung keluarga. Ia memutuskan untuk menghentikan pendidikannya.

Selain pernah mengeyam pendidikan di Perguruan Tinggi di Universitas Indonesia, Mahbub Djunaidi juga pernah belajar di
Kolombo, Srilangka pada tahun 1960. Mahbub Djunaidi yang menggeluti dunia jurnalistik mendapatkan kesempatan untuk study banding dalam bidang jurnalistik. Pengalamannya dalam hal jurnalistik semakin diasah dan dipertajam sewaktu beliau belajar di Kolombo, Srilangka (Setiawan, 2016, hlm. 23).

Mahbub Djunaidi sangat aktif di dalam organisasi Persatuan Wartawan Indonesia (PWI). Pada tahun 1963 di dalam Kongres XI PWI bulan Agustus di Jakarta Mahbub Djunaidi terpilih menjadi Wakil Ketua PWI (Persatuan Wartawan Indonesia) dan diketuai oleh Karim DP. Lalu, pada tanggal 4 sampai 7 November 1965 terpilih menjadi ketua umum PWI Pusat dari tahun 1965-1970 menggantikan Karim DP dan kemudian pada tahun 1978 terpilih menjadi Dewan Kehormatan PWI.

Sejak tahun 1970 selain aktif di dalam PWI, Mahbub Djunaidi pun menjadi kolumnis di Harian Kompas dan majalah Tempo. Ketika menjadi penulis tetap di kolom Harian Kompas, terlihat kentara kemampuan Mahbub menulis. Kolomnya mengandung humor, sinisme, bersifat santun, terkadang menyengat, berpihak kepada wong cilik dan kerakyatan. Ia menulis secara memikat dan disenangi oleh pembaca. Ia lancar bertutur, pintar bercakap-cakap, menyentuh aneka ragam topik, seperti kata orang Perancis: Le Causeur (Anwar, 2002, hlm. 401).

Di dalam organisasi Islam Mahbub Djunaidi sangat aktif di Nahdlatul Ulama (NU). Dalam organisasi mulamulanya menjadi ketua Ikatan Pemuda Pelajar Indonesia (IPPI) pada tahun 1952 sewaktu masih duduk di bangku SMP. Lalu, ketika SMA mulai bergabung ke dalam Ikatan Pelajar Nahdlatul Ulama 
(IPNU) yang merupakan kader partai NU. Ketika menjadi mahasiswa UI, Mahbub Djunaidi memilih untuk menjadi aktivis di kalangan mahasiswa. Di perguruan Tinggi tersebut ia mengikuti organisasi Himpunan Mahasiswa Islam (HMI). Pada saat itu HMI menjadi satu-satunya wadah mahasiswa Islam.

Pada tahun 1958 Mahbub Djunaidi bekerja sebagai wartawan di Harian Duta Masyarakat yang merupakan koran partai NU. Kepandaiannya dalam menulis akhirnya terpilih menjadi direktur Harian Duta Masyarakat pada tahun 1960-1970. Hal ini diperkuat oleh pernyataan Puspitasari (2013, hlm. 3) yang mengatakan bahwa :

"Dunia pers Indonesia tidak akan bisa melupakam nama Mahbub Djunaidi yang pernah tiga kali memimpin organisasi kewartawanan, PWI, Mahbub juga dikenal sebagai pemikir NU. Ia terjun ke dunia jurnalistik pada tahun 1958 mengisi Harian Duta Masyarakat yang kemudian ia menjadi Pemimpin Redaksinya pada tahun 1960-1970".

Pada tanggal 14-17 Maret 1960 IPNU mengadakan konferensi besar di Kaliurang Yogjakarta yang didalamnya membahas tentang perlunya didirikan suatu organisasi mahasiswa yang terlepas dari IPNU baik secara struktur oganisatoris maupun administratif (Alfas, 2015, hlm. 8). Setelah itu, dilaksanakan kembali konferensi besar I IPPNU pada tanggal 1416 April di Surabaya yang melangsungkan musyawarah mahasiswa NU se-Indonesia untuk membidani lahirnya Pergerakan Mahasiswa Islam Indonesia (PMII). Pada akhirnya Mahbub Djunaidi terpilih menjadi ketua umum PMII setelah keluar dari HMI.

Ketika menjadi seorang kolumnis, pemikiran Mahbub Djunaiditentangagama pada tahun 1970-1995 banyak ditungkan ke dalam tulisannya di koran. Pemikirannya tentang agama tidak terlepas dari paham Ahlussunnah Wal Jama'ah (Aswaja) yang telah melekat di dalan organisasi NU. Secara garis besar Aswaja merupakan suatu aliran pemahaman keagamaan yang bertujuan untuk mengamalkan syariat Islam secara murni sesuai dengan yang di kehendaki oleh Allah SWT. Ajaran Islam yang murni ialah ajaran yang diamalkan oleh Rasulullah SAW dan para sahabatnya. Cahlim (2012, hlm. 24) mengatakan bahwa "Ahlussunnah Wal Jama'ah merupakan kelangsungan yang alami dari kaum muslimin generasi pertama yang mengikuti dan menerapkan ajaran Nabi dalam prinsip-prinsip keagamaan”.

Aziz dkk. (2004, hlm. 61) mengatakan bahwa istilah Aswaja dimaknai sebagai suatu konstruksi pemikiran (pemahaman) dan sekaligus praktek keagamaan (Islam) yang didasarkan pada tradisi (sunnah) Rasulullah, para sahabatnya dan para Ulama mazhab. Yang terpenting dari pemikiran keagamaan Aswaja adalah konsistensinya dengan tradisi keagamaan yang dipraktekan Rasulullah dan para sahabatnya.

Mahbub Djunaidi berpandangan bahwa Aswaja merupakan suatu ideologi dan prinsip berpikir yang penting bagi seorang kaum muslim untuk menghadapi persoalan-persoalan keagamaan maupun urusan sosial kemasyarakatan. Sebagai seorang muslim yang taat harus membawa kehangatan kepada sesama manusia dan toleransi yang mengandung rasa saling 
menghargai sesuai dengan yang terdapat dalam prinsip-prinsip Aswaja (K.H. Nuril Huda, Wawancara, 15/3/2018).

Pemikirannya tentang Aswaja tidak terlepas dari organisasi Nahdlatul Ulama (NU) yang diikutinya sejak duduk di bangku SMP. Selain itu ayahnya merupakan seorang tokoh NU yang banyak mengajarkan ilmu-ilmu agama Islam sejak kecil kepada dirinya. Sehingga pada akhirnya Mahbub Djunaidi mengikuti jejak ayahnya untuk masuk ke dalam organisasi NU yang menganut paham Aswaja. Paham tersebut dijadikan sebagai landasan berfikir organisasi NU untuk menentukkan arah perjuangan dalam rangka memperbaiki umat.

Pemikirannya tentang Aswaja pun tidak terlepas dari kedekatannya dengan beberapa Kiai atau Ulama-Ulama di Indonesia yang menganut paham tersebut. Pada umumnya para Kiai dibesarkan dan didik di dalam lingkungan pesantren yang secara tegas memegang teguh paham Aswaja (Islam tradisional). Oleh karena itu hampir semua Kiai atau Ulama menjadi pembela yang tangguh paham tersebut. Dhofier (2011, hlm. 229) mengatakan bahwa sewaktu kaum Islam modern menganjurkan pembaruan ajaran-ajaran Islam, antara lain agar umat Islam tidak terbelenggu oleh ajaran-ajaran empat madzhab, yang mulai diperkenalkan di Jawa pada permulaan abad ke-20, para Kiai menentang gerakan pembaruan tersebut dengan membentuk suatu organisasi bernama "Jami'yyah Nahdlatul Ulama". Pernyataan tersebut diperkuat oleh Siddiq (2005, hlm. 27) yang mengatakan bahwa :

"Nahdlatul Ulama semenjak pertama berdirinya menegaskan diri sebagai penganut pengemban dan pengembang
Islam ala Ahlussunnah Wal Jama'ah. Dengan sekuat tenaga, Nahdlatul Ulama berusaha menempatkan diri sebagai pengamal setia dan mengajak seluruh kaum Muslimin, terutama para warganya untuk menggolongkan diri pada Ahlussunnah Wal Jama'ah".

Di dalam Aswaja terdapat beberapa sikap yang patut dicontoh seperti tawasuth (mengambil jalan tengah atau moderat), tawazun (seimbang di dalam menyelesaikan setiap persoalan) dan tazamuh (bersikap toleran, adil dan netral di dalam menghadapi perselisihan). Menurut Mahbub Djunaidi sikap-sikap tersebut dapat diimplementasikan di dalam kehidupan nyata. Hal ini diperkuat oleh pernyataan dari Isfandiari (Wawancara,9 Maret 2018) yang mengatakan bahwa "sebagai seorang muslim yang taat terhadap agama Islam menurut Mahbub Djunaidi semua tindakan harus mencontoh tabiat Rasulullah dan dipraktikan dengan nyata di kehidupan sehari-hari.

Mahbub Djunaidi tidak hanya menerapkan paham Aswaja di dalam kehidupan sehari-harinya saja, akan tetapi diterapkan pula di dalam organisasi Islam yang pernah diketuainya selama dua periode. Organisasi Islam tersebut bernama Pergerakan Mahasiswa Islam Indonesia (PMII). Salah satu peran yang sangat berkesan yang dilakukan oleh Mahbub Djunaidi di PMII adalah ketika menerapkan dasar Aswaja. Mahbub Djunaidi yang memelopori bahwa PMII harus berhaluan paham tersebut. Jika tidak ada Mahbub Djunaidi belum tentu PMII berasaskan paham tersebut. Penerapan bahwa PMII harus berhaluan Aswaja pun tidak hanya dilakukan oleh Mahbub Djunaidi seorang diri, akan 
tetapi dibantu oleh M. Zamroni yakni orang yang berpengaruh dan penggagas independensi PMII. M. Zamroni pun merupakan teman debat Ir.Soekarno dan tokoh yang senang berdemonstrasi (K.H. Nuril Huda, Wawancara, 15/3/2018). Pernyataan hasil wawancara dengan K.H. Nuril Huda pun diperkuat oleh pernyataan dari Alfas (2015, hlm.16) yang mengatakan bahwa pengertian Islam yang Aswaja yaitu konsep pendekatan terhadap ajaran agama Islam secara proporsional antara Iman, Islam dan Ihsan yang di dalam pola pikir dan pola perilakunya tercermin sifat-sifat selektif, akomodatif dan integratif.

Dalam pemikirannya tentang agama, Mahbub Djunaidi pun selalu memikirkan hal-hal yang berkaitan dengan kehidupan sosial kemasyarakatan. Banyak tulisantulisan tentang agama yang memberikan gambaran bagaimana menjadi seorang muslim yang alim dan berperan di dalam masyarakat. Hal itu ditunjukkan lewat tulisannya dengan memberikan perhatian dan pembelaan kepada rakyat terutama rakyat kecil. Tidak hanya itu di dalam tulisannya dituangkan juga rasa toleransi antar umat beragama, non rasis dan menjunjung tinggi hak asasi manusia.

Perhatian dan pembelaannya terhadap rakyat kecil menjadi salah satu misi hidupnya. Budairy (dalam Djunaidi dan Rasta, 2017, hlm. 68) mengatakan bahwa ada perilaku pribadi Mahbub Djunaidi yang lepas dari perhatian banyak orang. Ketika memimpin Duta Masyarakat tahun 6o-an, salah seorang staf administrasi di kantor redaksi bernama Mukmin, asal Solo, masih sangat muda. Mahbub Djunaidi berhasil "menyalurkan" Mukmin menjadi pegawai di kantor DPR-RI.
Rasa keberpihakannya kepada rakyat pun dituangkan dalam tulisannya yang berjudul "Sejak Kapan Rakyat Kecil Bikin Rumah Harus Pakai Arsitek?” dimuat di koran Pelita pada tanggal 13 Februari 1980. Ketika itu pemerintah akan mengeluarkan rancangan peraturan yang berdalihkan "modernisasi". Rancangan peraturan bab II tersebut berisi tentang perizinan mendirikan dan atau menghuni bangunan. Pasal 3 rancangan peraturan itu antara lain berbunyi sebagai berikut.

1. Untuk Perencanaan Arsitektur/ Konstruksi/Instalasi dan Perlengkapan Bangunan, pemilik diwajibkan menunjuk/menugaskan seorang Perencana/Biro Perencana dan seorang Direksi/Biro yang punya izin bekerja dari Gubernur Kepala Daerah.

2. Untuk pelaksanaan, pemilik wajib menunjuk pemborong yang punya izin bekerja dari Gubernur Kepala Daerah (kecuali bangunan-bangunan tertentu yang akan ditetapkan oleh Gubernur Kepala Daerah) serta harus menunjuk Direksi/Biro yang mempunyai izni bekerja dari Gubernur Kepala Daerah untuk tiap-tiap bidang Arsitektur, Konstruksi serta Instalasi dan Mekanikal.

Selain itu, pasal 21 dari bab II-nya pun berbunyi sebagai berikut, yaitu Izin mendirikan bangunan batal, apabila :

1. pemegang izin tidak lagi menjadi yang berkepentingan tanpa pemberitahuan tertulis dengan bukti-bukti hukum tentang pemilikan banguan dalam waktu selambat-lambatnya tiga bulan.

2. dalam waktu enam setelah pemberian izin belum dimulai dengan pelaksanaan pembangunan, atau pekerjaan yang 
telah dilaksanakan dianggap hanya sebagai persiapan.

3. pekerjaan belum selesai menurut jadwal pelaksaan atau dalam jangka waktu ditetapkan dalam izin bangunan.

Reaksi Mahbub Djunaidi melihat pasal rancangan tersebut beranggapan bahwa tentunya sudah jelas betapa rakyat kecil akan menghadapi kesulitan besar ketika hanya mempunyai sedikit uang untuk membuat rumah. Mereka harus memakai perencanaan yang disusun oleh arsitek yang punya izin bekerja yang dikeluarkan oleh Gubernur. Lalu, sesudah itu mereka harus menggunakan jasa pemborong yang harus punya izin bekerja yang dikeluarkan oleh Gubernur.

Di dalam tulisannya Mahbub Djunaidi mengatakan "sejak kapan rakyat kecil ketika akan membuat rumah harus memakai arsitek resmi ? sejak kapan rakyat kecil ketika akan membangun rumah harus memakai pemborong resmi ? sejak kapan rakyat kecil mampu membangun rumahnya menurut jadwal waktu yang ditentukkan ? bukankah mereka membuat rumah secara berdikit-dikit, beli kayu terlebih dahulu, jika ada rezeki lagi beli pasir dahulu, jika ada rezeki lagi beli balok dahulu, jika ada rezeki lagi beli kusen dahulu, jika ada rezeki lagi beli genteng dahulu, dan jika rezeki seret ubinnya boleh dipasang tahun depan? (Djunaidi, 1986, hlm. 17-18)".

Rasa perhatian dan pembelaannya terhadap rakyat pun termasuk kepada anak-anak pedagang asongan dan para pengemis cilik di persimpanganpersimpangan jalan. Anak-anak tersebut ditangkapi dengan tuduhan melanggar Peraturan Daerah (PERDA) NO. 11 tahun 1988. Peraturan tersebut antara lain berisikan tentang larangan bagi pedagang asongan dan mengancam menjatuhkan hukuman baik bagi pedagang maupun pembeli. Mahbub Djunaidi pun di dalam tulisannya mengatakan bahwa bukankah PERDA ini bertentangan dengan UUD 45 ? bukankah bunyi UDD 45 pasal 27 menyebutkan bahwa hak tiap warga negara atas pengajaran dan penghidupan yang layak ? bukankan pasal 34 UUD 45 menjamin fakir miskin dan negara akan memelihara mereka ? (Djunaidi dan Rasta, 2017, hlm. 69).

Di dalam hal kemanusiaan, Mahbub Djunaidi menunjukkan rasa toleransi dan sikap non rasis kepada orang-orang Tionghoa lewat tulisan-tulisannya. Dalam tulisannya Mahbub Djunaidi mengkritik diskriminasi Cina ikhwal pelayanan KTP dan lain-lain. Walaupun termasuk tokoh NU yang mulai terkenal dengan tulisan-tulisannya, Mahbub Djunaidi tetap menjaga dan berhubungan baik dengan pemeluk agama Kristen yang juga merupakan warga Tionghoa. Salah satu sikap toleran dan non rasis terhadap orang Tionghoa, Mahbub Djunaidi tulis dalam karyanya yang berjudul " Antara Rasialisme dan Dendam Ekonomi” dimuat di dalam koran Merdeka pada tanggal 13 Agustus 1973. Di dalam tulisannya tersebut menggambarkan suasana kota Bandung. Dirinya mengatakan bahwa hari Minggu 5 Agustus 1973, mulai lepas magrib sampai menjelang subuh, kota ini seperti sampah di bakar. Ratusan mobil, ratusan toko berikut barang-barang isinya habis dibakar. Mahbub Djunaidi berpendapat bahwa peristiwa ini lebih hebat ketimbang peristiwa rasialis " 10 Mei” sepuluh tahun sebelumnya. Ada hal yang paling menyedihkan di dalam pemandangan seperti ini yaitu toko-toko, 
rumah-rumah, bahkan dokter-dokter yang berada di sekitar daerah gawat pasang tulisan "milik pribumi" atau "milik bangsa Indonesia asli”, bahkan ada pula yang tak kepalang tanggung lagi menuliskan "milik orang Sunda”.

Asal mulanya terjadi sebuah insiden yakni seorang tukang gerobak yang terkena pukulan seorang keturunan Tionghoa karena mobilnya keserempet. Penghancuran total toko dan harta benda orang-orang keturunan Tionghoa hampir seantero Bandung itu tak lain dari pada suatu huru-hara rasialis. Peristiwa penghancuran itu tidaklah bisa disebut spontan karena jarak waktu antara terjadinya pemukulan dan gerakan penghancuan lebih dari tiga jam. Apalagi sifat penghancurannya yang begitu total, begitu luas daerah jangkauannya , berkilo-kilo meter dari daerah asal kejadian tidaklah patut disebut "perbuatan spontan”. Ini merupakan suatu bukti paling nyata tentang rasialisme, rasa benci yang terpendam, yang pada suatu waktu meledak secara membabi buta hanya karena soal-soal sepele.

Jarak yang memisahkan si asli dan si bukan asli itu, bukanlah semata-mata lantaran warna kulit. Bukan lantaran yang satu asli dan yang lain keturunan asing. Dorongan utama yang mempertajam jurang itu adalah perbedaan tingkat hidup ekonominya. Dan anggapan umum sekarang ini sudah begitu rupa si asli keadaan ekonominya semakin lama makin jelek, sedangkan si bukan asli makin lama makin bagus. Si asli ibarat mati langkah dalam usaha ekonominya, si bukan asli makin gampang dan makin licih jalannya. Si asli sulit dapat kredit dan fasilitas obyekan pemerintah, si bukan asli tinggal ketuk pintu dan semua kesempatan tersedia baginya. Si pejabat menganak tirikan si asli tapi menganak emaskan si bukan asli. Ringkasnya masyarakat menganggap adanya diskiriminasi kepada mayoritas, bukannya kepada minoritas (Djunaidi, 1986, hlm. 29-31).

Berdasarkan tulisannya tersebut dapat dilihat bahwa Mahbub Djunaidi orang yang anti rasialisme. Rasialisme merupakan istilah yang digunakan untuk menekankan perbedaan sosial dan budaya antar ras. Menurutnya bangsa ini tidak akan menjadi bangsa yang kuat selama rasa kesukuan, rasa asli dan bukan asli, rasa mendeskriminasi sesama warga negara masih terdapat di dalam kalbu masyarakat. Sehingga, hal ini akan membuat bangsa cepat rapuh dan mudah patah.

Dalam kehidupan sosial kemasyarakatan, Mahbub Djunaidi sangat menjunjung tinggi Hak Asasi Manuisa. Pembelaannya pada penghargaan Hak Asasi Manusia sangat terlihat jelas di dalam tulisannya yang mengatakan bahwa "tanamkanlah ke kepala anakanakmu bahwa Hak Asasi itu sama pentingnya dengan sepiring nasi”. Sepanjang hidupnya baik di dalam lisan maupun tulisan Mahbub Djunaidi mempunyai sikap yang jelas dan tegas dalam hal memperjuangkan kepentingan rakyat dan Hak Asasi demi kemajuan negeri yang dicintainya karena dirinya merasa prihatin terhadap kelemahan jiwa bangsa dan rakyat Indonesia yang terjebak dalam irasionalitas, feodalisme, dan ketidakadilan. Joe (dalam Djunaidi dan Rasta, 2017, hlm. 51) mengatakan bahwa beberapa hal penting saya ingat sebelum Mahbub Djunaidi wafat adalah betapa ia memperjuangkan hak-hak para 
jurnalis yang berjuang membela tanah air dan sangat pedas mengkritik jurnalis yang takut dan jadi boneka Orde Baru. Hal yang sangat luar biasa lainnya adalah kejujurannya. Lewat ucapan juga tulisan ia berjuang sendiri meluruskan sejarah yang banyak diplintirkan rezim Orde Baru saat itu. Ia sangat berani menentang itu sendirian, seorang single fighter.

Ketika menjadi seorang kolumnis pun, Mahbub Djunaidi banyak menuangkan pemikirannya tentang politik. Pemikirannya tentang politik berlandaskan politik ala Islam yang selalu berbicara tentang hubungan Islam, demokratis dan negara. Sebagai seorang pemikir politik Mahbub Djunaidi sangat menjunjung tinggi demokrasi. Agama Islam dan demokrasi memiliki hubungan yang sangat erat yang memberikan petunjuk bagi manusia dalam mencapai kehidupan yang damai dan sejahtera. Bagi Indonesia, demokrasi yang penuh dengan nilai kemanusiaan akan lebih terwujud bila Islam serta dalam kegiatannya. Kita sebut Islam karena ia merupakan agama yang terbanyak penganutnya di negeri ini, juga karena nasionalisme kita dahulu berkembang lebih mudah karena ajaran Islam yang dianutnya oleh sebagian besar rakyat (Karni, 2006, hlm. 266).

Ketika Indonesia berada di bawah pemerintahan Orde Baru, Mahbub Djunaidi banyak mengkritik pemerintahan tersebut lewat tulisan-tulisannnya pada saat menjadi seorang kolumnis. Bersebrangan dalam beberapa hal prinsipil dirinya menentang rezim Soeharto, menentang kesewenang-wenangan, menentang prilaku rezim yang sangat kapitalis birokrat menentang bisnis keluarga yang menggurita, menentang kebebasan Pers yang dibung- kam, kebebasan berpendapat dan lainlain.

Mahbub Djunaidi mengkritik sistem pemerintahan Orde Baruyang dianggapnya tidak sejalan dengan sistem demokrasi yang ada di Indonesia. Hal ini dikarenakan dalam praktiknya yang menjalankan pemerintahan bukan rakyat melainkan para elite. Pemerintah yang baik ialah yang berorientasi kepada kepentingan rakyat banyak, bukan berorientasi kepada sekelompok kecil tuan-tuan besar yang hidup di gedung bertingkat dikelilingi kaca seperti permen dalam toples (Djunaidi, 1986, hlm. 16)

Pemikiran Mahbub Djunaidi tentang politik pada tahun 1970-1995 pun selalu berbicara tentang hubungan antara NU dan negara. Pada tahun 1945 merupakan awal perjalanan politik praktis NU. Ketika itu, NU bersama dengan organisasi Islam lainnya membentuk partai yang bernama Masyumi (Majelis Syuro Muslimin Indonesia) yang berdiri pada tanggal 7 November 1945. Pada saat itu, NU menjadi anggota istimewa dan mendapat jatah kursi di Masyumi. Hal ini pun diperkuat oleh pernyataan dari Feillard (dalam Shobacha, 2012, hlm. 106) yang mengatakan bahwa pada saat Masyumi didirikan untuk pertama kalinya NU memasuki urusan pemerintahan sebab ditempatkan sebagai subordinasi di dalamnya. Namun, ketika Nahdlatul Ulama menjadi partai politik, NU tetap tidak meninggalkan urusanurusan yang selalu ditanganinya seperti urusan pendidikan, urusan sosial, dakwah dan muamalah.

Ketika diadakannya fusi partai pada tahun $1973 \mathrm{NU}$ harus berfusi dengan kelompok Islam lain dalam Partai Pembangunan Persatuan (PPP). Fusi 
partai-partai Islam ini pada awalnya menguntungkan NU namun semakin lama NU merasa menjadi pihak yang di rugikan oleh PPP. Hingga akhirnya pada tahun 1984 NU beserta para Kiai banyak menelan banyak kekecewaan dan keputusasaan. Melihat situasi politik yang semakin pelik, akhirnya pada muktamar ke-25 di Surabaya, Rais Amm Kiai Wahab Hasbullah menghimbau agar para aktivis kembali ke Khittah 1926. Kembalinya NU ke Khittah 1926 merupakan istilah yang berarti NU kembali menjadi organisasi masyarakat dan keagamaan. Gagasan ini banyak mendapatkan respon positif dari kalangan NU lainnya seperti Abdurrahman Wahid dan pendukung lainnya. Hal ini pun diperkuat oleh pernyataan yang diungkapkan oleh Ubaid dan Bakir (2015, hlm. 177) yang mengatakan bahwa sejumlah kalangan di dalam maupun di luar NU meminta supaya warga NU tidak terlu berpolitik, baik secara individual maupun organisasi. Mereka menilai jika jagat politik hanya mendatangkan "banjir" kemafsadahan atau kemadaratan dibanding kemanfaatannya. Mereka memvonis keterlibatan "punggawa" NU dalam berpolitik sebagai suatu kesalahan besar yang membuat citra NU semakin karut-karut.

Melihat hasil muktamar NU di Situbondo, Mahbub Djunaidi tidak setuju terhadap hasil keputusan Khittah NU 1926 yang menginginkan NU kembali kepada organisasi Islam dan kemasyarakatan serta melepaskan keterkaitan dari dunia politik secara organisatoris. Mahbub Djunaidi beranggapan bahwa politik adalah jalan yang efektif untuk mencapai sebuah tujuan. Karena bila dilihat dari arti kata politik secara singkat ialah usaha untuk menggapai kehidupan yang baik.
Hal ini pun diperkuat oleh pernyataan dari Setiawan (2016, hlm. 50) yang mengatakan bahwa NU memang tidak bisa dipisahkan dengan urusan politik, karena memang sejak tahun 1952 NU yang mengganti baju dari Jami'yah keagamaan menjadi sebuah partai politik. Budaya politik sudah mengakar kuat dalam tubuh NU dan para tokoh-tokohnya.

Mahbub Djunaidi beranggapan bahwa masih banyak warga NU yang menginginkan ormas keagamaannya menjadi partai politik. Ia tidak bisa membayangkan warga NU yang sekitar 20 jutaan umat pada tiap pemilu hanya berdiri di luar pagar dan cukup terbatas pada tukang beri suara. Menurut Mahbub Djunaidi sejak kelahirannya NU selalu bersentuhan dengan politik. NU dalam dunia politik baik dalam partai maupun kursi pemerintahan akan memudahkan cita-cita NU dan umat Islam untuk mencapai tujuan karena menurutnya politik merupakan jalan satu-satunya untuk mencapai tujuan tanpa harus dibatasi oleh keputusan Khittah NU 1926 yang melarang NU untuk ikut berpolitik praktis.

\section{SIMPULAN}

Mahbub Djunaidi merupakan seorang kolumnis yang sudah gemar menulis sejak kecil. Keikutsertannya di dalam organisasi Nahdlatul Ulama (NU) membuat tulisantulisannya yang dimuat di dalam koran tidak terlepas dari pemikiran agama dan politik. Pemikiran Mahbub Djunaidi tentang agama pada tahun 1970-1995 tidak terlepas dari paham Ahlussunnah Wal Jama'ah yang telah menjadi ideologi organisasi NU. Ahlussunnah Wal Jama'ah merupakan suatu aliran pemahaman 
ULFIYANA LATIFAH DAN AGUS MULYANA

PEMIKIRAN MAHBUB DJUNAIDI TENTANG AGAMA DAN POLITIK PADA TAHUN 197O-1995

keagamaan yang bertujuan untuk mengamalkan syariat Islam sesuai dengan yang diamalkan oleh Rasulullah SAW dan para sahabatnya. Dalam pemikirannya tentang agama Mahbub Djunaidi pun selalu memikirkan hal-hal yang berkaitan dengan kehidupan sosial kemasyarakatan. Hal ini ditunjukkan lewat tulisannya dengan memberikan perhatian kepada rakyat kecil, berbicara tentang toleransi umat beragama, non rasis dan menjunjung hak asasi manusia.

Pemikiran Mahbub Djunaidi tentang politik pada tahun 1970-1995 banyak berbicara tentang hubungan Islam, demokrasi dan negara serta hubungan NU dan negara. Mahbub merupakan seorang tokoh pemikir yang sangat menjunjung tinggi demokrasi. Hal ini dikarenakan Mahbub Djunaidi menginginkan NU di dalam negara berpolitik secara demokratis. Menurutnya Islam dan demokrasi memiliki hubungan yang sangat erat. Kedua nya memberikan kehidupan yang damai dan sejahtera bagi manusia. Mahbub Djunaidi pun menginginkan organisasi NU di dalam negara ikut terlibat dalam dunia politik.

\section{DAFTAR PUSTAKA}

\section{Buku}

Alfas, F. (2015). PMII dalam SimpulSimpul Sejarah Perjuangan. Jakarta: PB PMII \& Intimedia.

Anwar, R. (2002). In Memoriam: Mengenang yang Wafat. Jakarta: Penerbit Buku Kompas.

Aziz, A.A. dkk. (2004). Islam Ahlussunnah Wal Jama'ah: Sejarah Pemikiran dan Dinamika NU di Indonesia. Jakarta: Pengurus Lembaga Pendidikan Ma'arif Nahdlatul Ulama.
Dhofier, Z. (2011). Tradisi Pesantren: Studi Pandangan Hidup Kyai dan Visinya Mengenai Masa Depan Indonesia. Jakarta: LP3ES.

Djunaidi, M. (1986a). Humor Jurnalistik. Jakarta: Indera Aksara.

Djunaidi, M. (1996b). Mahbub Djunaidi Asal Usul. Jakarta: Kompas.

Djunaidi, M.I \& Rasta, I. (2017). Bung: Memoar tentang Mahbub Djunaidi. Jakarta: Yayasan Pustaka Obor Indonesia.

Gottschalk, L. (2008). Mengerti Sejarah. Jakarta: Universitas Indonesia Press.

Ismaun. (2005). Pengantar Sejarah Sebagai Ilmu dan Wahana Pendidikan. Bandung: Historia Utama Press.

Karni, A, S. (2006). Hajatan Demokrasi: Potret Jurnalistik Pemilu Langsung Sampul Islam Indonesia dari Moderat Hingga Garis Keras. Jakarta: PT. Media Informasi.

Puspitasari, V. E. (2013). Mahbub Djunaidi: Studi tentang Peranannya Dalam Sejarah Pers Islam di Indonesia Pada Tahun 1960-1970. (Skripsi). UIN Sunan Ampel, Surabaya.

Setiawan, E.E. (2016). Mahbub Djunaidi: Studi pemikiran tentang Khittah Plus NU Tahun 1987.(Skripsi). UIN Sunan Ampel, Surabaya.

Siddiq, A. (2005). Khittah Nahdliyyah. Surabaya: Khalista.

Sjamsuddin, H. (2007). Metodologi Sejarah. Yogyakarta: Ombak.

Ubaid, A \& Bakir, M. (2015). Nasionalisme Islam Nusantara. Jakarta: PT. Kompas Media Nusantara.

\section{Jurnal}

Effendi, M.R. (2013). Pemikiran Politik Islam di Indonesia: Antara Simbolistik dan Substantivisik (Kajian Pra, Masa, 
FACTUM

Volume 8 No.1, April 2019

dan Pasca Orde Baru). Jurnal: Ulumul Shobacha, N. (2012). Strategi Politik Qur'an, 19 (1), 89-105.

Nahdlatul Ulama di Era Orde Baru.

Putra, O.E. (2008). Hubungan Islam Jurnal: Review Politik. 2(1), 99-113.

Politik Masa Orde Baru. Jurnal:

Dakwah, 9 (2), 185-201. 